\title{
HUGE COMPLEX MEDIASTINAL MASS PRESENTING AS A RARE VARIANT OF LYMPHOBLASTIC LEUKEMIA/LYMPHOMA.
}

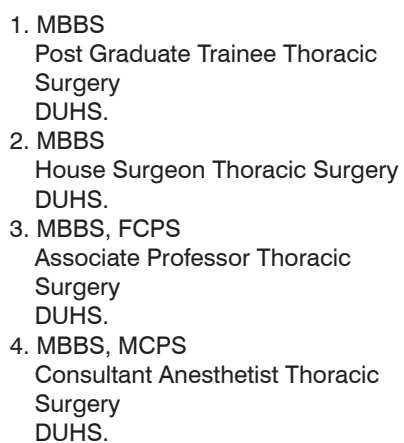

Correspondence Address:

Dr. Hira Pervez

Department of Thoracic Surgery

DUHS.

drhirapervez@gmail.com

Article received on: 16/09/2019

Accepted for publication: 25/01/2020

\begin{abstract}
Hira Pervez ${ }^{1}$, Salwa Pervez ${ }^{2}$, Soomro Niaz ${ }^{3}$, Saima Imam ${ }^{4}$
ABSTRACT... The mediastinum is the space that separates the lungs from the rest of the chest. The most common mediastinal masses are neurogenic tumors (20\% of mediastinal tumors), followed by thymoma(15-20\%). Others include lymphoma, pheochromocytoma, germ cell tumors, including teratoma, thyroid tissue, and parathyroid lesions. Lymphoblastic leukemias/ lymphomas are neoplasms of precursor $\mathrm{T}$ and $\mathrm{B}$ cells, also known as lymphoblasts. The World Health Organization (WHO) classification has unified these entities as precursor B and T-cell lymphoblastic leukemia/lymphoma. We present a rare variant of non-Hodgkins lymphoma in a 12-year-old female who complained of worsening dyspnea and lower left-sided chest pain. The patient was treated empirically with anti-tuberculous drugs without relief. On admission, a CT scan chest showed an anterior mediastinal mass that was approximately $25 \times 12.5 \mathrm{~cm}$ adherent to the mediastinal structures, which was removed with the preservation of the phrenic nerve. Histopathology suggested small cells with hyperchromatic nuclei and positive tumor markers. The rarity of this condition can lead to delayed or even misdiagnoses. Therefore, any mass should raise a concern of T-LBL.
\end{abstract}

Key words: Anterior Mediastinal Mass, Mediastinum, Non-Hodgkins Lymphoma, Respiratory Compromise.

Article Citation: Pervez H, Pervez S, Niaz S, Imam S. Huge complex mediastinal mass presenting as a rare variant of lymphoblastic leukemia/lymphoma. Professional Med J 2020; 27(10):2271-2278.

DOI: $10.29309 / T P M J / 2020.27 .10 .4156$

\section{INTRODUCTION}

The mediastinum is the space that separates the lungs from the rest of the chest. The most common mediastinal masses are neurogenic tumors (20\% of mediastinal tumors), followed by thymoma (15-20\%). Others include lymphoma, pheochromocytoma, germ cell tumors, including teratoma, thyroid tissue, and parathyroid lesions. ${ }^{1,2}$ Lymphoblastic leukemias/ lymphomas are neoplasms of precursor $\mathrm{T}$ and $\mathrm{B}$ cells, also known as lymphoblasts. The World Health Organization (WHO) classification has unified these entities as precursor $B$ and T-cell lymphoblastic leukemia/lymphoma. In Pakistan, though $\mathrm{T}$ cell lymphomas have been reported more as compared to the west ${ }^{3}$ overall $\mathrm{T}$ cell lymphomas are less frequent all over the world except the Far East Asian countries. The staging system used in pediatric Lymphoblastic Lymphoma was coined at the St. Jude's Hospital ${ }^{4}$
Table-I, devised to reflect more accurately the extent of disseminated disease, contiguous lymph nodal involvement, and unrespectable masses. The Ann-Arbor staging system is used more often in adult patients ${ }^{5}$ Table-II. With current treatments, the overall survival rate at 5 years in children with lymphoblastic lymphoma is $80-90 \%$, and the overall survival rate in adults is $45-55 \%$. Disease-free survival rates at 5 years range from $70 \%$ to $90 \%$ in children and from $45 \%$ to $55 \%$ in adults. We present this case as a rare variant of Non-Hodgkin's Lymphoma, presenting as a huge $(25 \mathrm{~cm} \times 12.5 \mathrm{~cm})$ mass in the mediastinum in a 12-year-old female.

\section{Case}

A 12-year-old female was referred from another hospital. The patient has a contact history of Tuberculosis. Five months earlier he presented with left-sided lower chest pain associated with 
shortness of breath. On examination, there was decreased chest movement, a dull note on percussion, and decreased breath sounds on the lower half of the left side of the chest. A chest $X$-ray revealed a left-sided pleural effusion. Tube thoracostomy was performed and Anti-Tb drugs were empirically started. The patient deteriorated further and had multiple aspirations (therapeutic pleural aspirations).

It is interesting to note that her Complete Blood Count showed 57\% lymphocytes and $32 \%$ neutrophils, despite a normal total leukocytes count. Workup for TB came back negative. Computed Tomography (CT) chest with contrast showed partly defined enhancing mass extending from the mediastinum toward the left chest cavity with moderate pleural effusion and multiple nodular enhancing pleural masses. A provisional diagnosis of a Germ Cell Tumor (GCT) was made.

Tumor markers for Alpha-fetoprotein, B-HCG, and serum LDH were all within normal limits. Following workup, left-sided Thoracotomy was planned to resect the mediastinal mass. A huge anterior mediastinal mass, approximately $25 \mathrm{~cm}$ x $12.5 \mathrm{~cm}$, adherent to the sternum, arch of aorta, ascending aorta, diaphragm, pericardium, and the thoracic wall was seen per-operatively with both cystic and solid components. The cystic collection was hemorrhagic (approximately $1200 \mathrm{ml})$.
The phrenic nerve was adherent to the tumor but was spared. Histopathology revealed small cells with hyperchromatic nuclei, fibrous septae with scattered blood vessels. Subsequently, tumor markers were sent. CD3, CD5, CD99, and LCA were positive, whereas CD10, CD20, FL1, BCL2, and Desmin were negative. Ki67 was greater than $95 \%$.

Based on these findings the final diagnosis of $\mathrm{T}$ cell lymphoblastic lymphoma/leukemia was made. The patient was referred to the hematology/ oncology and was also followed in our outpatient department regularly.

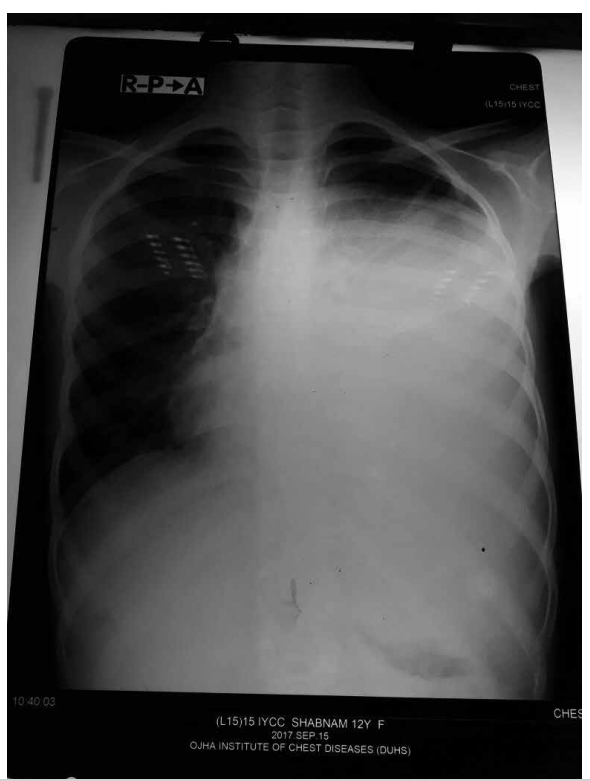

Preoperative Chest X-Ray (PA view) showing a homogenous opacity covering the left lower half of the lung field.

\begin{tabular}{|c|l|}
\hline Stage & \multicolumn{1}{c|}{ Characteristics } \\
\hline I & Single tumour (extranodal) or single anatomic area (nodal), with the exclusion of mediastinum or abdomen. \\
\hline II & $\begin{array}{l}\text { Single tumour (extranodal) with regional lymph node involvement. Two or more nodal areas on the same } \\
\text { side of the diaphragm. Two single extranodaltumours with or without regional lymph node involvement on } \\
\text { the same side of the diaphragm. Primary gastrointestinal tract tumour, usually in the ileocecal area, with or } \\
\text { without involvement of associated mesenteric lymph nodes only, grossly completely resected }\end{array}$ \\
\hline III & $\begin{array}{l}\text { Two single tumours (extranodal) on opposite sides of the diaphragm. Two or more nodal areas above and } \\
\text { below the diaphragm. All the primary intrathoracictumours (mediastinal, pleural, thymic). All extensive } \\
\text { primary intra-abdominal disease, unresectable, all para-spinal or epidural tumours, regardless of other } \\
\text { tumour site(s) }\end{array}$ \\
\hline IV & $\begin{array}{l}\text { Any of the above with initial CNS and/or BM involvement } \\
\text { Table-I. St. Jude children's research hospital staging system. }\end{array}$ \\
\hline
\end{tabular}




\begin{tabular}{|c|c|c|c|c|c|c|c|c|c|c|}
\hline Stage & \multicolumn{10}{|c|}{ Characteristics } \\
\hline 1 & \multicolumn{10}{|c|}{ Involvement of a single lymph node region (I) or a single extranodal site (IE). } \\
\hline II & \multicolumn{10}{|c|}{$\begin{array}{l}\text { Involvement of two or more lymph node regions on the same side of the diaphragm (II) or localized } \\
\text { involvement of an extralymphatic site (IIE). }\end{array}$} \\
\hline III & \multicolumn{10}{|c|}{$\begin{array}{l}\text { Involvement of lymph nodes regions on both sides of the diaphragm (III) or localized involvement of an } \\
\text { extralymphatic site (IIIE) or spleen (IIIs) and both (IIIEs). }\end{array}$} \\
\hline IV & \multicolumn{10}{|c|}{$\begin{array}{l}\text { Diffuse or disseminated involvement of one or more extralymphatic organs with or without associated lymph } \\
\text { node involvement. Localized involvement of liver or bone marrow is also considered stage IV. }\end{array}$} \\
\hline A & \multicolumn{10}{|c|}{ Absence of systemic symptoms } \\
\hline $\mathrm{B}$ & \multicolumn{10}{|c|}{$\begin{array}{l}\text { Presence of systemic symptoms (fever of no evident cause, night sweats and weight loss }>10 \% \text { of body } \\
\text { weight in the last } 6 \text { months). }\end{array}$} \\
\hline $\mathrm{X}$ & \multicolumn{10}{|c|}{ The presence of bulky mass, such as a lesion of $10 \mathrm{~cm}$ or more in the longest diameter. } \\
\hline \multicolumn{11}{|c|}{ Table-II. Ann Arbor staging system is as follows. } \\
\hline & & $\begin{array}{c}\text { Reiter et } \\
\text { al. } \text {. }^{13]}\end{array}$ & $\begin{array}{l}\text { Neth et } \\
\text { al. } \text {. }^{|14|}\end{array}$ & $\begin{array}{l}\text { Mora et } \\
\text { al. } \text {.15] }^{-15}\end{array}$ & $\begin{array}{c}\text { Burkhardt et } \\
\text { al. } \text {. }^{16]}\end{array}$ & $\begin{array}{l}\text { Ducassou et } \\
\text { al. } \text {. }^{[1]]}\end{array}$ & $\begin{array}{l}\text { Termuhlen et } \\
\text { al. } \text {. }^{[1]]}\end{array}$ & $\begin{array}{l}\text { Termuhlen et } \\
\text { al. } \text { [5] }^{[5]}\end{array}$ & $\begin{array}{c}\text { Sandlund et } \\
\text { al. }{ }^{[1]]}\end{array}$ & 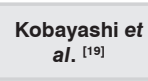 \\
\hline No. of Pati & & 105 & 21 & 95 & 156 & 53 & 60 & 254 & 41 & 29 \\
\hline \multicolumn{11}{|c|}{ Involved sites } \\
\hline \multicolumn{2}{|c|}{ Mediastinum } & $88 \%$ & - & $48 \%$ & $78 \%$ & $9 \%$ & - & - & $83 \%$ & $86 \%$ \\
\hline \multicolumn{2}{|c|}{ Pleuro-pericardic } & - & - & - & - & $2 \%$ & - & - & $54 \%$ & - \\
\hline \multicolumn{2}{|c|}{ Lymph Nodes } & - & $77 \%$ & - & - & $52 \%$ & $12 \%$ & - & - & - \\
\hline \multicolumn{2}{|c|}{ CNS } & $3 \%$ & - & $4 \%$ & $1 \%$ & - & - & $5 \%$ & $7 \%$ & - \\
\hline \multicolumn{2}{|c|}{$\mathrm{BM}(<25 \%)$} & $15 \%$ & - & - & $26 \%$ & $13 \%$ & - & - & $16 \%$ & - \\
\hline \multicolumn{2}{|c|}{ Skin/Subcutaneous } & - & $22 \%$ & $20 \%$ & - & $22 \%$ & $9 \%$ & - & $1 \%$ & - \\
\hline \multicolumn{2}{|c|}{ Bone } & - & $29 \%$ & $10 \%$ & - & $24 \%$ & $18 \%$ & - & $10 \%$ & - \\
\hline \multicolumn{2}{|l|}{ Gonads } & - & - & $1 \%$ & - & $7 \%$ & - & - & - & - \\
\hline \multicolumn{2}{|c|}{ Head and Neck } & - & - & $12 \%$ & - & $3 \%$ & $4 \%$ & - & - & - \\
\hline \multicolumn{2}{|c|}{ Kidney } & - & - & - & - & $2 \%$ & - & - & - & - \\
\hline \multicolumn{2}{|c|}{ Digestive Tract } & - & - & - & - & $2 \%$ & - & - & - & - \\
\hline \multicolumn{11}{|c|}{ Table-III. } \\
\hline
\end{tabular}

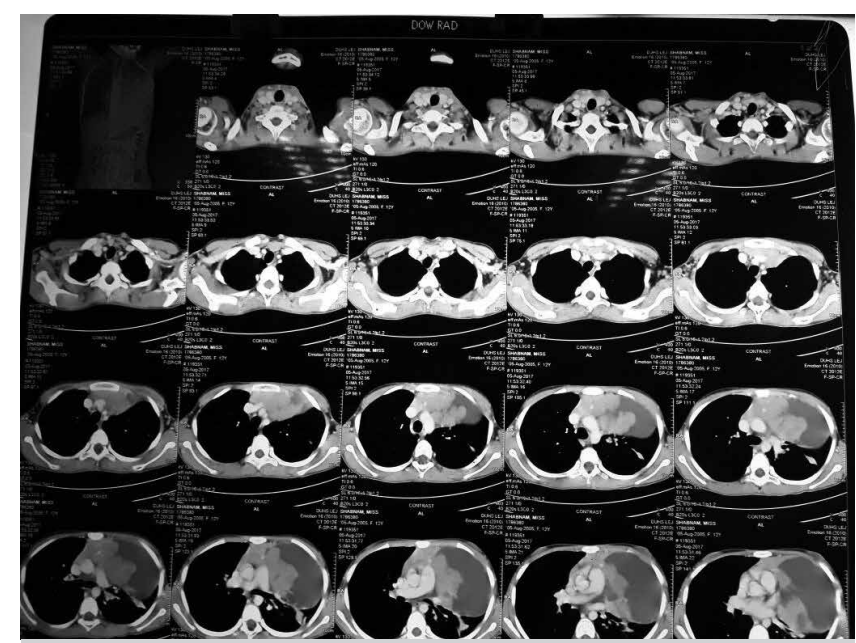

Computed Tomography (CT) chest with contrast (mediastinal window) showing partly defined enhancing mass extending from mediastinum toward left chest cavity with moderate pleural effusion and multiple nodular enhancing pleural masses. Computed Tomography (CT) chest with contrast (mediastinal window).

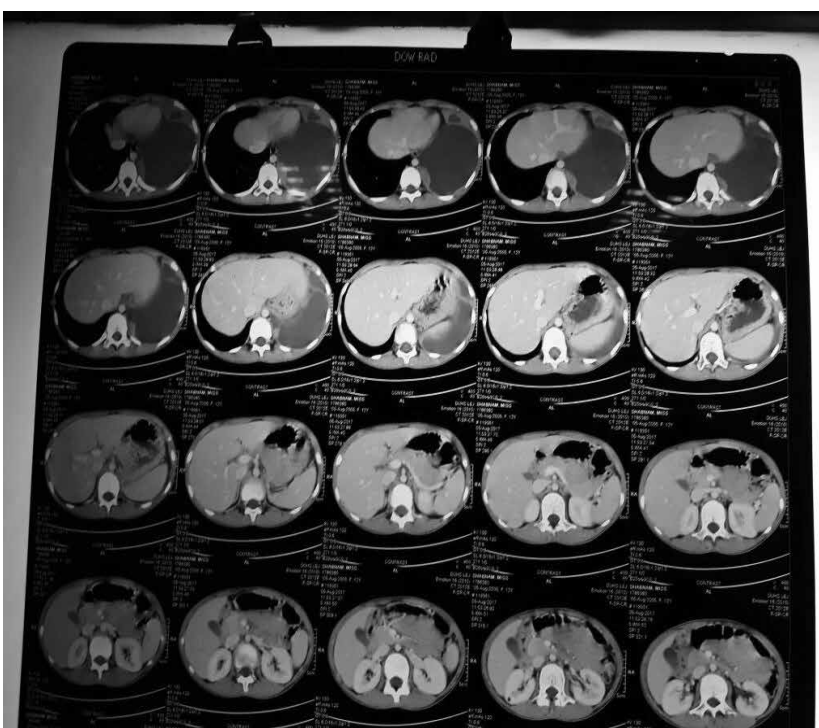

Computed Tomography (CT) chest with contrast (mediastinal window). 


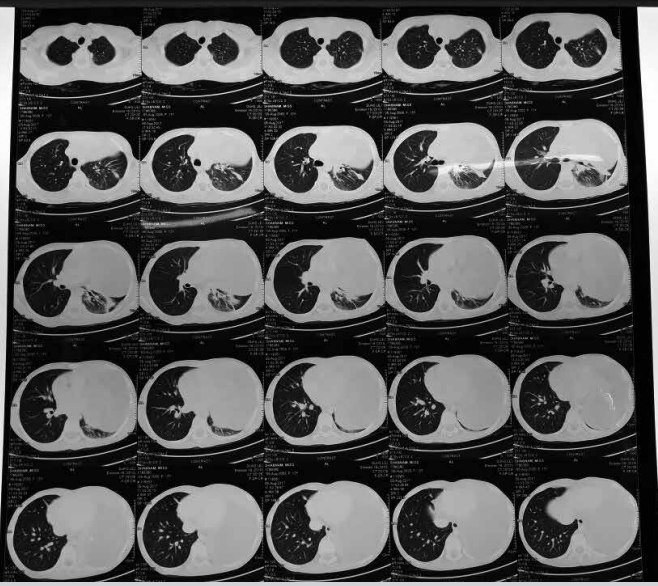

Computed Tomography (CT) chest with contrast (lung window).

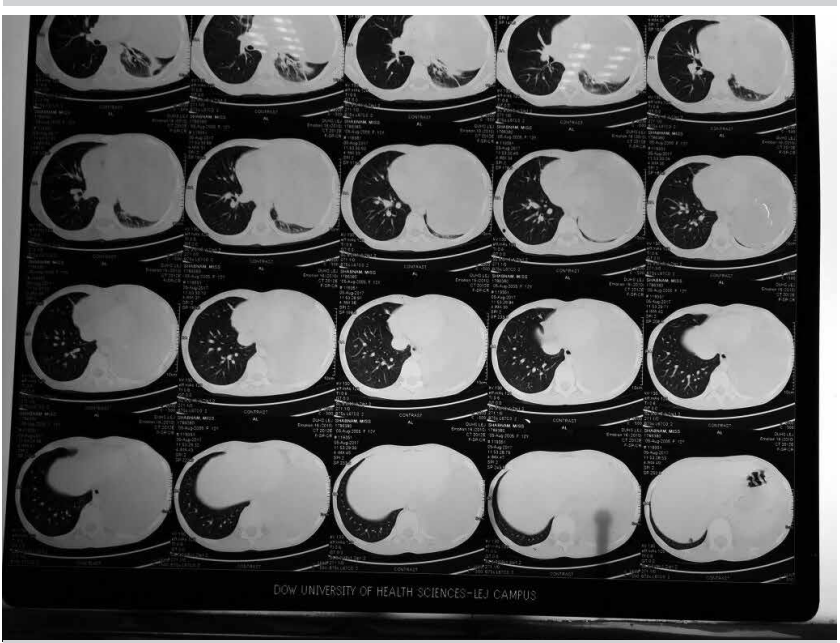

Computed Tomography (CT) chest with contrast (lung window).

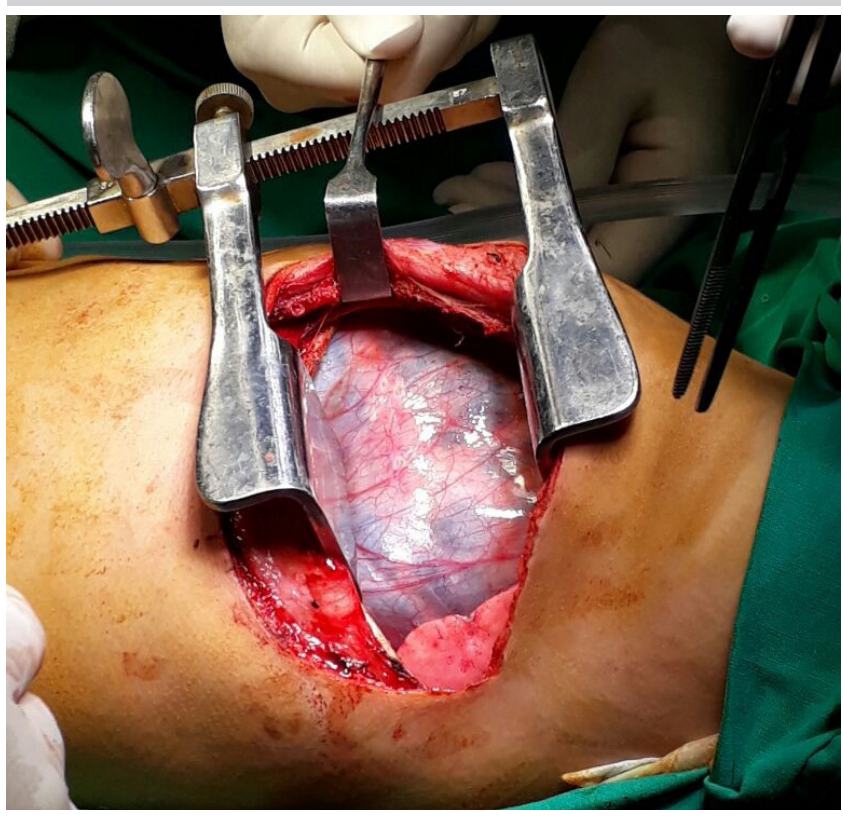

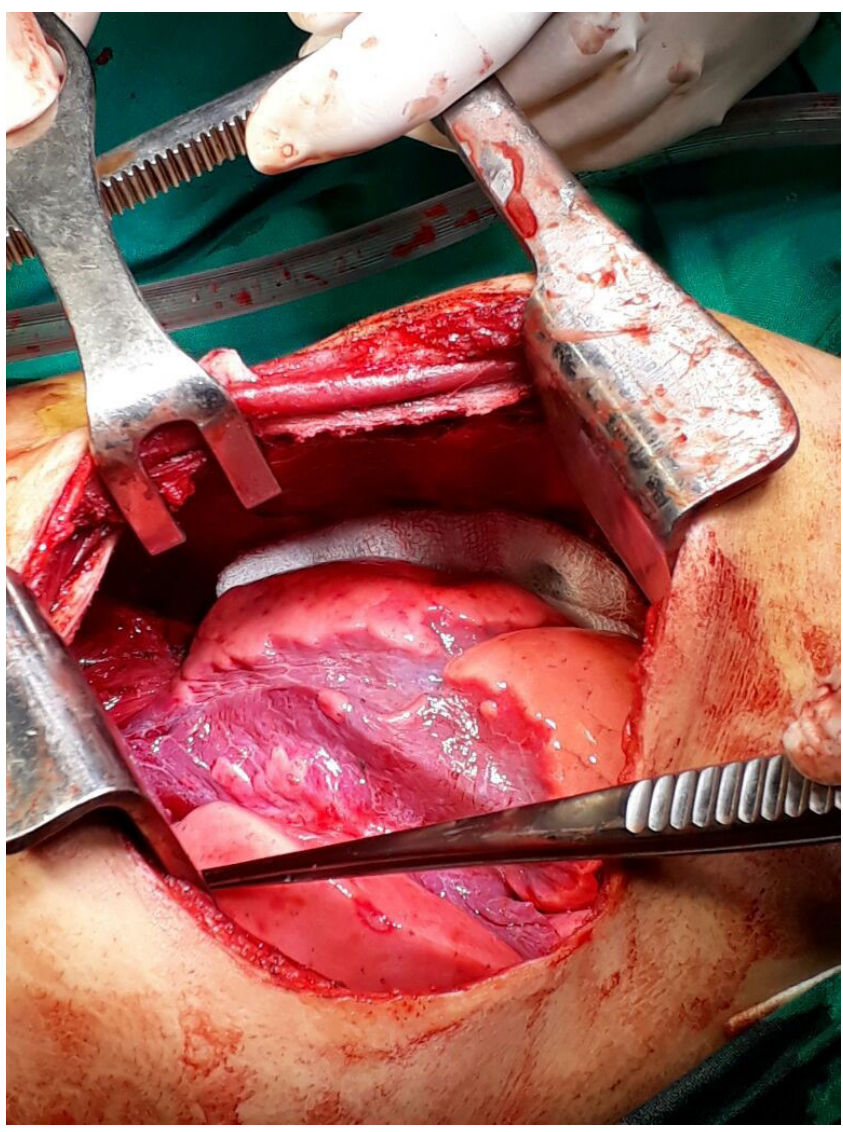

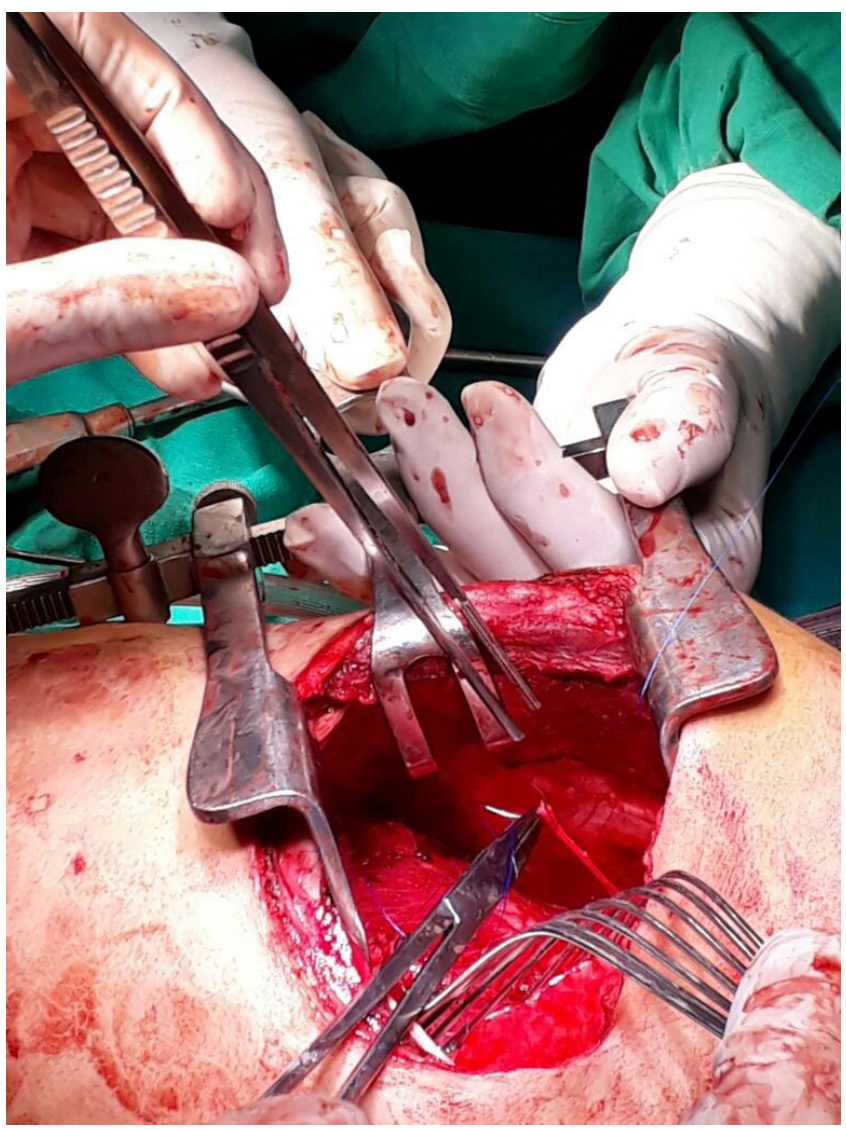



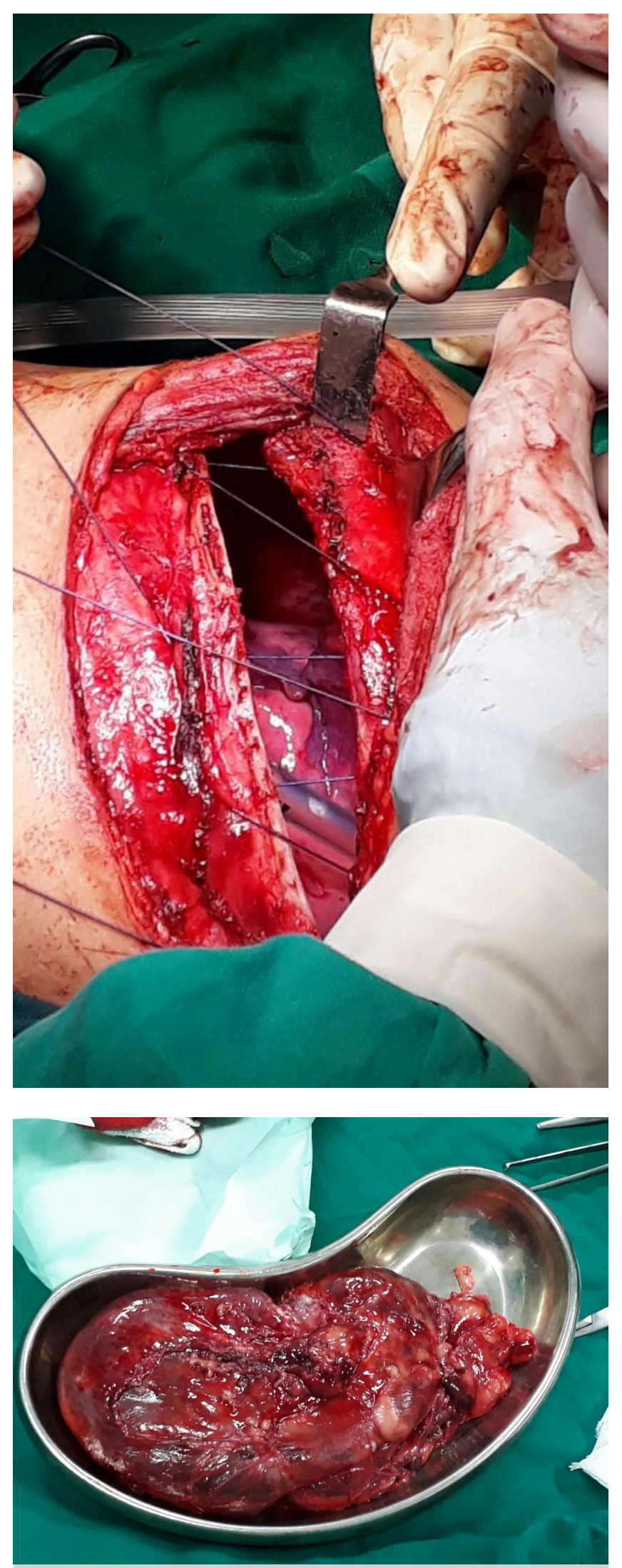

The complete resected tumor.

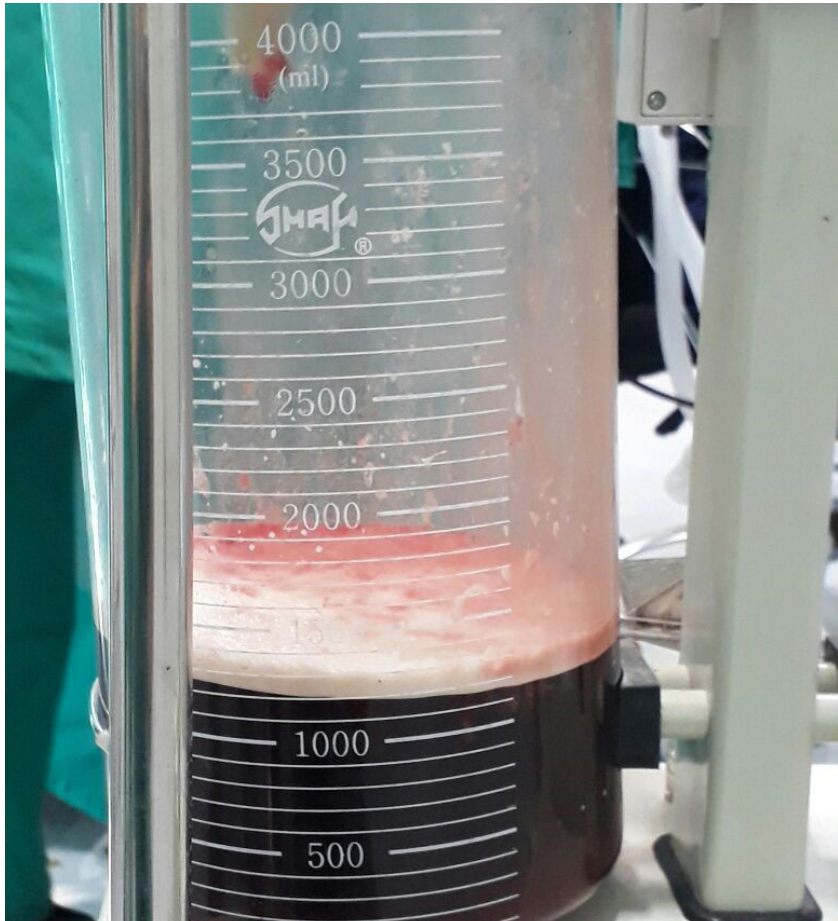

The hemorrhagic collection from the cystic component of the tumor.

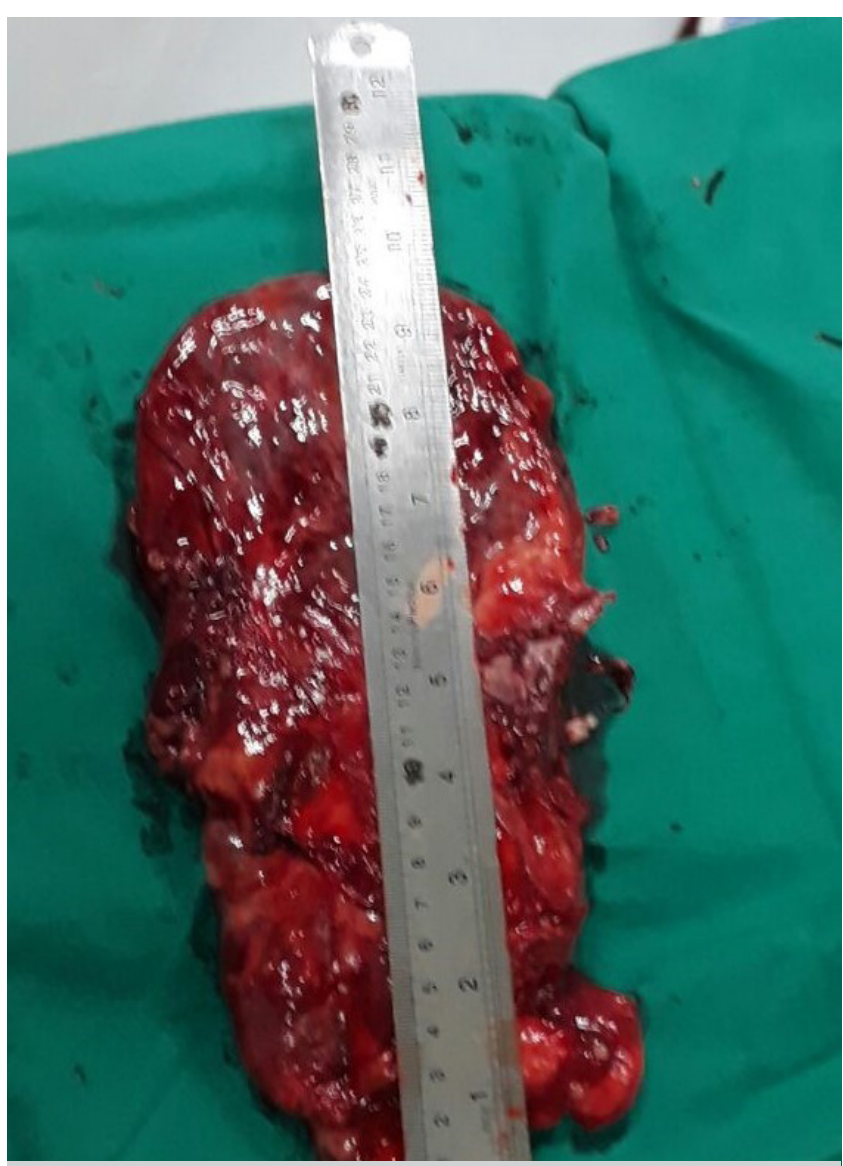

Dimensions of the resected tumor mass. 


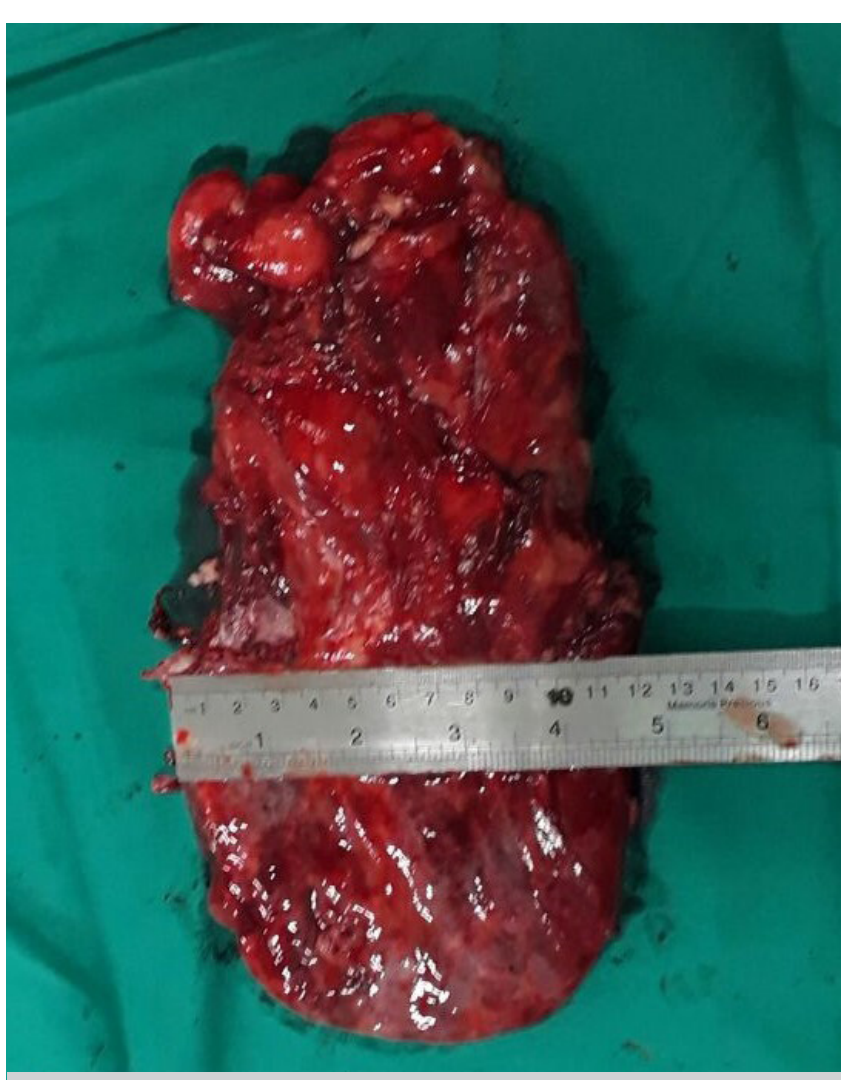

Dimensions of the resected tumor mass.

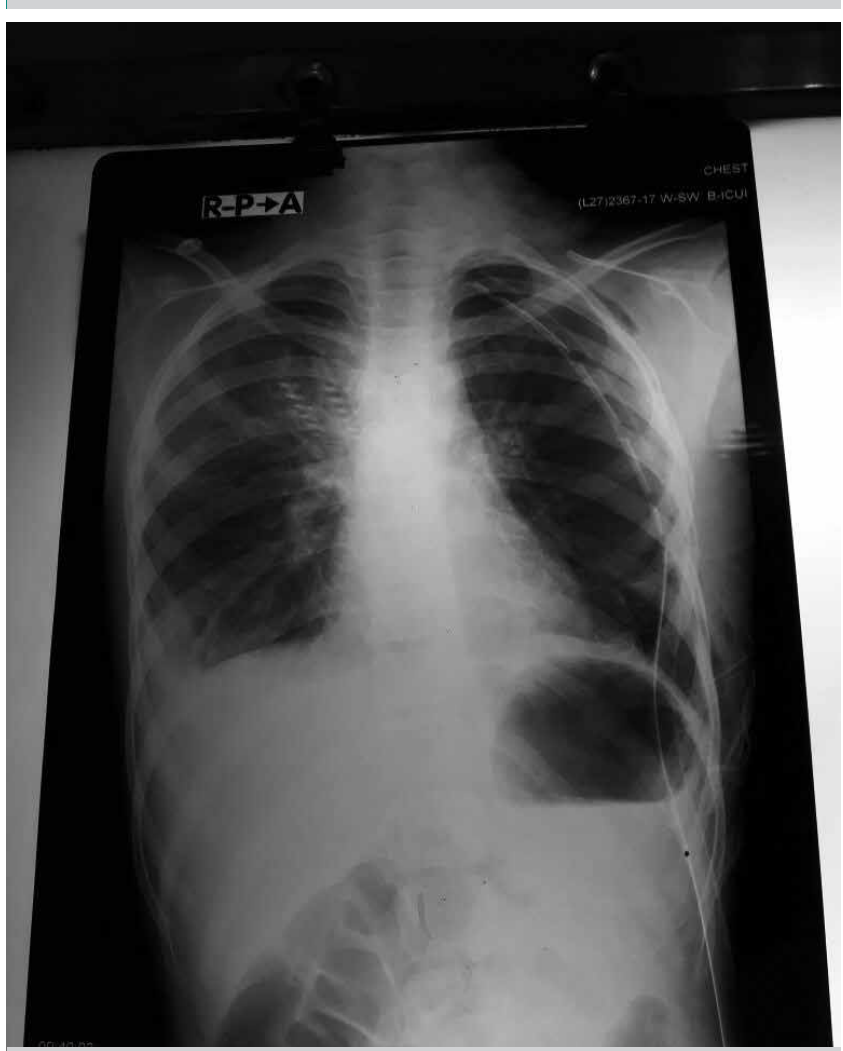

The immediate post-operative chest X-Ray with the chest tube in place.

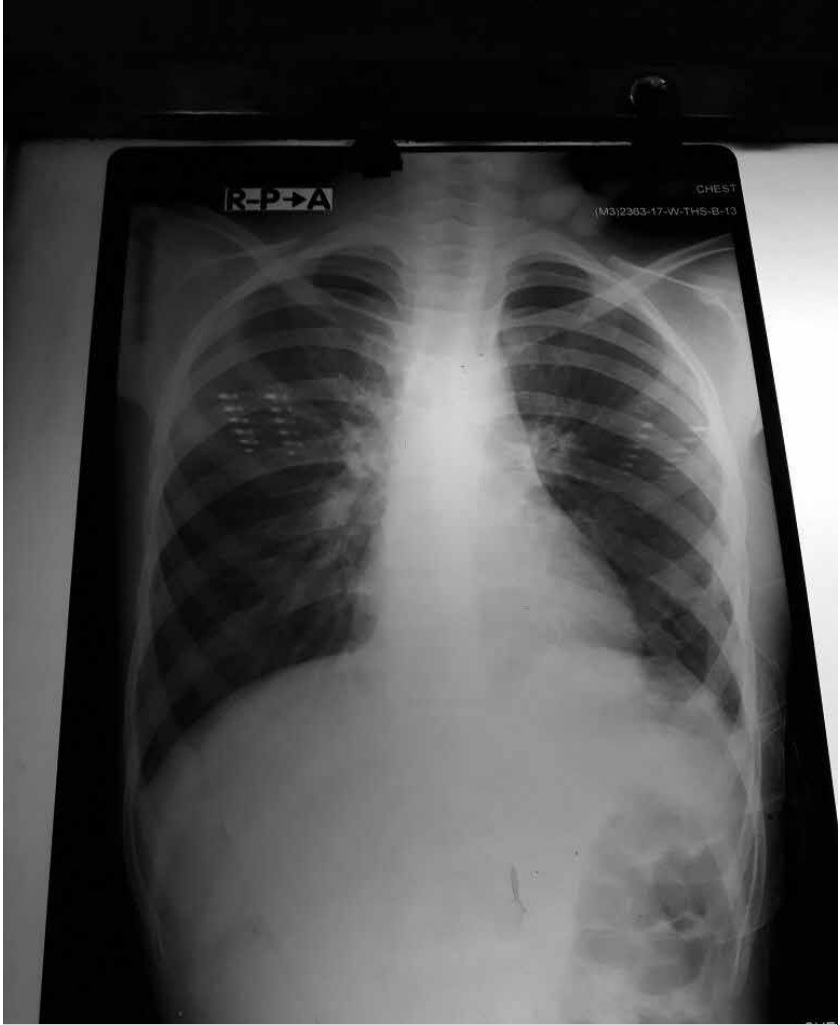

Post-operative chest X-Ray after removal of the chest tube.

\section{DISCUSSION}

T-cell lymphoblastic lymphoma/leukemia (T-LBL) can present as a mediastinal mass and is often accompanied by shortness of breath due either to compression of the superior vena cava or pericardial or pleural effusion. ${ }^{6}$ T-LBL patients, compared to those with B-cell lymphoblastic lymphoma/leukemia (B-LBL), show younger age, a higher rate of mediastinal tumors or bone marrow involvement ${ }^{7}$, this is in accordance with our case. Patients are usually males in their teens to twenties and present with lymphadenopathy in cervical, supraclavicular and axillary regions $(50 \%)$, or with a mediastinal mass $(50 \%-75 \%)$ as small size mass. ${ }^{8}$ Our patient however, was a young female in her pre-teens and. In most patients, the mediastinal mass is anterior, bulky, and associated with pleural effusions, superior vena cava syndrome, tracheal obstruction, and pericardial effusions. The most striking characteristic of our case is the huge size of the tumor (approximately $25 \times 12.5 \mathrm{~cm}$ ) and in our extensive research, we could not find another case with similar dimensions 
The most frequent sites of involvement observed in children are summarized in Table-III. ${ }^{9}$, $10,11,12,13,14,15,16$

As is evident in Table-III, the most commonly involved site is the mediastinum, which is the case in our patient as well. In most patients, the mediastinal mass is anterior, bulky, and associated with pleural effusions, superior vena cava syndrome, tracheal obstruction, and pericardial effusions. They present with stage IV disease (80\%) and B symptoms (50\%) and in the majority of cases elevated serum lactate dehydrogenase (LDH) levels. Less commonly, patients present extranodal disease (e.g., skin, testis and bone involvement). Although the bone marrow is normal in the majority of cases at presentation, about $60 \%$ of patients develop BM infiltration and subsequently leukemic phase. ${ }^{17}$

The assessment of the disease extent is the same as for other aggressive lymphomas and includes a computed tomography (CT) scan of chest which provides clinically useful information when invasion of the mass into adjacent structures or pleural or lung metastasis are demonstrated. $A^{18} \quad$ fluorodeoxyglucose positron-emission tomography (FDG PET) assay is also currently being applied to primary mediastinal masses in the preoperative staging of thoracic malignancies. FDG PET has been shown to be helpful in differentiating benign from malignant mediastinal tumors, and in evaluating response to treatment of mediastinal lymphomas. ${ }^{18,19}$ Unfortunately, we did not have FDG PET scanning at our hospital. Magnetic resonance imaging (MRI) on the other hand, is useful for a suspect involvement of the spine, skull, and brain structures, or the heart. Evaluation of bone marrow (cytology and histology) and cerebrospinal fluid cytology is also necessary for the detection of bone marrow ( $<25 \%$ blast cells in LBL) and CNS involvement.

Current treatment strategies are based on intensive multidrug Acute Lymphoblastic Leukemia-type chemotherapy, including CNS prophylaxis, with or without mediastinal radiation therapy (MRT), depending on protocol design and early therapeutic response. The introduction of Acute Lymphoblastic Leukemia-type regimens led to a significant improvement of results, particularly in the pediatric population.

\section{CONCLUSION}

In this case, T-cell lymphoblastic lymphoma/ leukemia presented as a huge anterior mediastinal mass that, in this location, age group, gender and given the size was thought to be a germ cell tumor. The mass was surgically resected on only upon histopathology was revealed to be T-cell lymphoblastic lymphoma/leukemia. Therefore the uniqueness of our case lies in the fact that a T-LBL can present with such a huge mass that could be mistaken for other more common diagnoses.

Copyright $(25$ Jan, 2020.

\section{REFERENCES}

1. Macchiarini $P$, Ostertag $H$. Uncommon primary mediastinal tumors. Lancet Oncol. 2004; 5 (2):107-18.

2. Davis RD, Oldham HN, Sabiston DC. Primary cysts and neoplasms of the mediastinum: Recent changes in clinical presentation, methods of diagnosis, management, and results. Ann. Thorac. Surg. 1987; 44 (3):229-37.

3. Aziz Z, Rehman A, Akram M, Saeed A. Non-Hodgkin's lymphoma in Pakistan: A clinic pathological profile of 175 patients. J Pak Med Assoc. 1999; 49 (1):11-5.

4. Sandlund JT, Pui CH, Zhou Y, et al. Results of treatment of advanced-stage lymphoblastic lymphoma at St Jude Children's Research Hospital from 1962 to 2002. Ann Oncol. 2013; 24 (9):2425-9.

5. Cortelazzo S, Ponzoni M, Ferreri AJ, et al. Lymphoblastic Iymphoma. Crit Rev OncolHematol. 2011; 79 (3):33043.

6. Portell CA, Sweetenham JW. Adult lymphoblastic lymphoma. Cancer J. 2012;18 (5):432-8

7. Ellin $F$, Jerkeman $M$, Hagberg $H$, et al. Treatment outcome in T-cell lymphoblastic lymphoma in adults -a population-based study from the Swedish Lymphoma Registry. ActaOncol. 2014; 53 (7):927-934.

8. Streuli RA, Kaneko Y, Variakojis D, et al. Lymphoblastic lymphoma in adults. Cancer. 1981; 47 (10): 2510-2516. 
9. Ducassou S, Ferlay C, Bergeron C, et al. Clinical presentation, evolution, and prognosis of precursor B-cell lymphoblastic lymphoma in trials LMT96, EORTC 58881, and EORTC 58951. $\mathrm{Br} \mathrm{J}$ Haematol. 2011; 152 (4):441-51.

10. Patel JL, Smith LM, Anderson J, et al. The immunophenotype of T-lymphoblastic lymphoma in children and adolescents: A Children's Oncology Group report. Br J Haematol. 2012; 159 (4):454-61.

11. Reiter A, Schrappe M, Ludwig WD, et al. Intensive ALL-type therapy without local radiotherapy provides a $90 \%$ event-free survival for children with T-cell lymphoblastic lymphoma: A BFM group report. Blood. 2000; 95 (2):416-21.

12. Neth $O$, Seidemann $K$, Jansen $P$, et al. Precursor B-cell lymphoblastic lymphoma in childhood and adolescence: clinical features, treatment, and results in trials NHL-BFM 86 and 90. Med PediatrOncol. 2000; $35(1): 20-7$.

13. Mora J, Filippa DA, Qin J, et al. Lymphoblastic lymphoma of childhood and the LSA2-L2 protocol: The 30-year experience at Memorial-Sloan-Kettering Cancer Center. Cancer. 2003; 98 (6):1283-91.
14. Burkhardt B, Woessmann W, Zimmermann M, et al. Impact of cranial radiotherapy on central nervous system prophylaxis in children and adolescents with central nervous system-negative stage III or IV Iymphoblastic lymphoma. J ClinOncol. 2006; 24 (3):491-9.

15. Termuhlen AM, Smith LM, Perkins SL, et al. Outcome of newly diagnosed children and adolescents with localized lymphoblastic lymphoma treated on Children's Oncology Group trial A5971: A report from the Children's Oncology Group. Pediatr Blood Cancer. 2012; 59 (7):1229-33.

16. Termuhlen AM, Smith LM, Perkins SL, et al. Disseminated lymphoblastic lymphoma in children and adolescents: Results of the COG A5971 trial: A report from the Children's Oncology Group. $\mathrm{Br} J$ Haematol. 2013; 162 (6):792-801.

17. Copelan EA, McGuire EA. The biology and treatment of acute lymphoblastic leukemia in adults. Blood. 1995; 85 (5):1151-1168.

18. El-Bawab $\mathrm{H}$, Al-Sugair AA, Rafay $M$, et al. Role of flourine-18 fluorodeoxy glucose positron emission tomography in thymic pathology. Eur J Cardiothorac Surg. 2007; 31 (4):731-739.

19. Kubota K, et al. PET imaging of primary mediastinal tumors. Br J Cancer 1996; 73 (7):882-886.

\begin{tabular}{|c|c|c|c|}
\hline \multicolumn{4}{|c|}{ AUTHORSHIP AND CONTRIBUTION DECLARATION } \\
\hline Sr. \# & Author(s) Full Name & Contribution to the paper & Author(s) Signature \\
\hline 1 & Hira Pervez & 1st Author & Jisiageng \\
\hline 2 & Salwa Pervez & 2nd Author & \\
\hline 3 & Soomro Niaz & 3rd Author & \\
\hline 4 & Saima Imam & 4th Author & $2 \operatorname{aingum}$ \\
\hline
\end{tabular}

